\title{
A Blended-Learning Program Based on the Progressive Theory to Develop the Yemeni EFL Teachers' Performance
}

\author{
A dissertation \\ submitted in partial fulfillment of the requirements for the award of Ph. Degree in \\ Education. Curriculum and Instruction (EFL) \\ Presented by: \\ Abdul-Razzaq Z. A. Al-Jarmouzi. \\ Supervised by: \\ Dr. Asmaa Ghanem Gheith \\ Professor of curriculum and \\ instruction (EFL) \\ Faculty of Education -Ain \\ Shams University \\ Dr. Badr Abdul-Fattah Abdul- Kafi \\ Lecturer of curriculum and \\ instruction (EFL) \\ Faculty of Education-Ain Shams \\ University
}

\author{
Dr. Ismael Masaud Naji \\ Associate professor of curriculum and \\ instruction (EFL) \\ Faculty of Education - Sana'a University
}




\begin{abstract}
The present study aimed to identify the effect of using a blended learning program based on the progressive theory on developing the Yemeni EFL teachers' performance both linguistically and pedagogically. Through the study, the one group quasi experimental design was adopted, and $16 \mathrm{EFL}$ male and female teachers enrolled in study at Al-Showkani Higher Institute for Qualifying and Training Teachers were involved as participants. Data was collected through three main instruments, namely: a performance observation checklist, a performance test, and a self-assessment sheet. Results of the study revealed that there was a statistically significant difference between the mean scores of participants in the pre-post administration of performance observation checklist in favor of the post administration, and there was a statistically significant difference between the mean scores of participants in the pre-post administration of performance test in favor of the posttest. In addition, the results showed that the effect size (d) of the blended-learning program based on the progressive theory both in relation to performance observation checklist and performance test was large on promoting the Yemeni EFL teachers' performance according to Cohen's criteria. The study ended with some recommendations as well as suggestions for further research in the light of the results obtained.
\end{abstract}

Key words: progressive theory, blended learning, developing EFL teacher performance.

هدفت هذه الدراسة إلى التعرف على أثر استخدام برنامج تعلم مدمج قائم على النظرية التقدمية

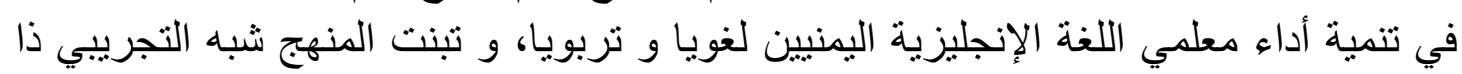

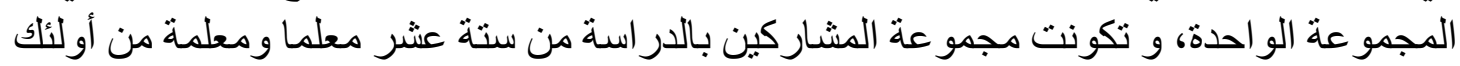
الملتحقين بقسم اللغة الإنجليزية بالمعهد العالي لتدريب و تأهيل المعلمين الثين أثناء الخدمة (الثنوكاني)،

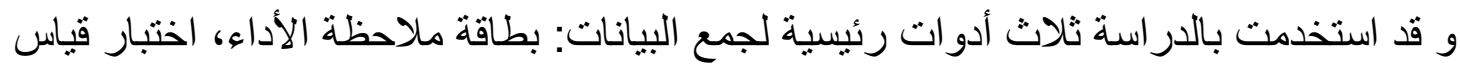

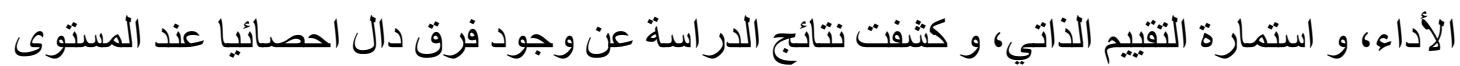

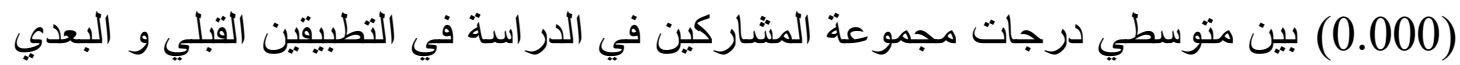

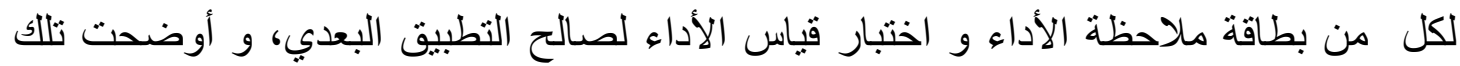

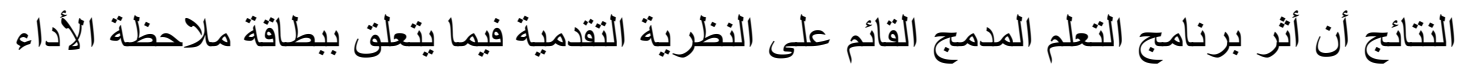

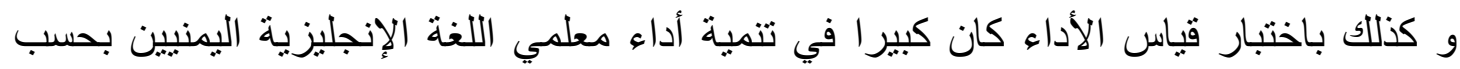

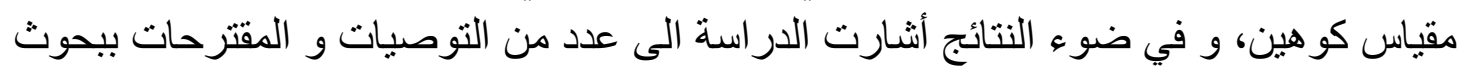




\section{Introduction:}

In the past, teaching and learning were submitted to the idea of transmission of heritage to generations. This was often done through subject-centered, discipline-oriented, standard-based education, where children were expected to absorb rote knowledge and memorize information to demonstrate mastery of content of the subject matter. Teachers used to consider learners as passive vessels into which they pour knowledge regardless of their individual needs and differences.

However, a pedagogical movement called progressivism appeared and began to cause great impact over the world. The progressive education movement dominated among waves of education innovators throughout the $20^{\text {th }}$ century has promoted the philosophy of educational institutions reform and has been historically accompanied with John Dewey emerging as he and his wife explained that the function of his school (1896-1904) was not to educate the values found in the society, but to invent new standards and ideals, and thus lead to a gradual change in conditions. Thus, progressive educators promoted the idea that humans are social beings who learn best in a democratic environment sharing real-life activities with others.

According to (Sadovnik, Cookson, \& Semel, 2001), growing numbers of such progressive educators started to believe that traditional approaches of education were not developing thoughtful, capable, wellrounded citizens who could contribute to a rapidly changing democratic society. Instead, those educators asserted that learning should be based on experiential learning, a curriculum that responds to learners' needs and interests, child-centered education, freedom, equity and individualism.

English is taught in Yemen as a foreign language and in public schools it is studied right from the first preparatory grade to the third secondary grade. The series known as "the Crescent" is the prescribed course on English assigned to school students. The Crescent series is based on the communicative approach to teaching/learning a language. The Yemeni students study the Crescent practicing English just inside the 
classrooms' walls, therefore, their background knowledge of it is stated to be low and merely superficial.

In the age of informatics, technology plays a vital role in all aspects of life, particularly, in the field of education. King (2002) remarked that blended online class discussions had the potential of prompting critical thinking, dynamic interactive dialogue, and substantial peer-to-peer interaction. Similarly, Hooper (2003) highlighted that blended courses proved to be more effective than fully online courses as they can create positive relationship between face to face and online environments.

The American society for training and development listed blended learning as one of the top ten trends merged in the knowledge delivery industry (Rooney, 2003). Similarly, Garrison \& Kanuka (2004) stated that blended learning has the power to promote deep learning.

In view of that, the application of blended instruction has quickly increased because instructors believe that varied delivery modes can enhance learners' satisfaction of the learning experience as well as their learning outcomes (Lim \& Morris, 2009). Furthermore, since either pure e-learning or regular face-to-face learning hold some weaknesses and strengths, it is better to mix the strengths of both learning environments to develop a new mode of delivery called blended learning (Azizan, 2010).

Bath \& Bourke (2010) assert that blended learning technologies can: 1) broaden the opportunities, spaces and resources available for learning, 2) engage and motivate learners through interactivity and collaboration, 3) support the provision of information and resources to learners, and ultimately 4) support course management activities including communication, scoring, assessing and giving feedbacks.

Similarly, Marsh (2012) states that we, as educators, always use a "fusion" of teaching approaches to provide as a rich learning environment as possible for our learners. In addition, what is nice of that is the expectation of our learners to use technology in and out of the classroom as part of their learning process. According to Saritepeci \& Mustafa, et al. (2015), using blended learning modes was proved more effective in enhancing learner achievement than face-to-face instruction. 
Many researchers believe that among other recently instructional process components including curriculum, teaching, learner, assessment, and overall quality assurance, teachers are thought to be the most important element influencing learner academic success and/or failure. Furthermore, it is obvious that after teachers have been working in the field for some time, their qualifications, knowledge and competencies become outdated, or there might be a lack of appropriateness between what those teachers have and what their educational institutions require due to enormous changes in the field.

Therefore, it is so vital to enhance and develop those teachers' performance, and the starting point for achieving such a goal is to have an effective teacher evaluation system which specifically spots areas and aspects that require some kinds of professional development. Through such professional development, EFL teachers can improve their language performance as well as update their pedagogical knowledge in areas such as second language acquisition, curriculum development, current trends concerned with English language teaching/learning, and integrating between theory and practice.

In the current study, a strong relationship may be established between progressivism and blended learning on one side and EFL teacher performance on the other side. This relationship may be illustrated in the way that such huge as well as remarkable thoughts, visions, and insights of progressivists towards learner and language learning/teaching process can best be virtually practiced and realized through a blended learning system with the purpose of enhancing the Yemeni EFL teachers' performance, both linguistically and pedagogically.

\section{Context of the problem:}

Many colleges and universities are adapting their education in a way to include an emphasis on content knowledge, increased use of educational technologies, creation of professional development, and ongoing training programs. Here it is worth noting that progressive education consistently seeks to go beyond the classroom walls (international journal of progressive education, 2013). 
Besides regular face-to-face instruction, it might be of great value to employ modern technology or what is referred to as (electronic or computer-mediated learning) for the first time in Yemen with special reference to the research participants (EFL teachers enrolled in study at AlShowkani Higher Institute for Qualifying and Training Teachers) with the purpose of developing these teachers' performance both linguistically and pedagogically performance. In this regard, Alhamzi (2017) conducted a quasi-experimental study to measure the effect of strategies of blended learning and peer learning on developing overt reading and functional writing for the seventh preparatory grader learners in Yemen.

Results of the study showed that blended learning strategy was effective in developing skills of overt reading and functional writing, and that the strategy of blended learning was more effective than the strategy of peer learning in developing overt reading skills for the seventh preparatory grade learners. In addition, results revealed there was no statistically significant difference at the level (0.05) between the mean scores of students of the first experimental group (blended learning) and the second experimental group (peer learning) in the posttest of functional writing skills.

Similarly, Nassar (2017) carried out a study to investigate the effect of using a blended learning program on enhancing the integration of tenth graders' reading of English narrative texts with their ability to write critically about them. Results showed that the blended learning program used was effective in promoting the integration of the tenth graders' reading of narrative texts with their critical writing abilities and, further, in developing their ability to navigate and use technology to enhance learning.

As denoted earlier, research shows that an inspiring and informed teacher is considered as the most crucial factor affecting learner achievement. So, it is vital to focus on how to train and support both innovative and experienced educators as well as enhance their performance.

In this context, Ali (2009) conducted a study to evaluate the Egyptian EFL primary teachers' performance in the light of Pharos 
standards. The study adopted the two-group quasi-experimental design. Results indicated that there was a statistically significant difference between the mean scores of participants of both groups, i. e., experimental and control, in relation to teaching performance in favor of the experimental group, and that EFL teachers' performance was less than the required average. Furthermore, the results showed that years of experience were proved to be an effective factor in improving teaching performance, and that teacher's evaluation is considered as one of the most important factors leading to the improvement of teaching performance and subsequently the improvement of the overall educational process.

Zuheer (2013) carried out a study with the purpose of developing teaching performance of EFL teachers at Sana'a secondary schools in the light of their professional and specialist needs. A list including the most required needs for English teachers at Sana'a secondary schools was prepared. The list of needs mainly consisted of effective communication skills, reflection, integrating language skills, and intercultural competence. The quasi-experimental design of the study depended on a voluntary basis of choosing 25 teachers as participants of the study. In the light of the reviewed literature, a training program was designed and implemented over a period of seven weeks. Results indicated that the proposed program was highly effective in developing the teaching performance of the participants concerning the four predetermined targeted needs.

Similarly, Yousif (2017) carried out a study which aimed at developing EFL teachers' teaching performance in the light of $21^{\text {st }}$ century skills using a training program based on Gardner's five minds model. The study used a mixed methods research design of collecting and analyzing quantitative and qualitative data. The findings indicated that the participants' overall teaching performance improved significantly due to the proposed training program with professional values on top of the competences that have been improved, followed by practical teaching skills and then professional knowledge. 


\section{Statement of the problem:}

The pilot study revealed that the Yemeni EFL teachers' performance is almost insufficient both linguistically and pedagogically, therefore, the researcher suggested the progressive theory as an umbrella through which a blended learning program could be used to develop their performance.

\section{Purpose of the study:}

The present study aimed at measuring the effect of using a blended learning program based on the progressive theory on developing the Yemeni EFL teachers' performance both linguistically and pedagogically.

\section{Study questions:}

What is the effect of using a blended-learning program based on the progressive theory on developing the Yemeni EFL teachers' performance?

This question can be divided into these sub-questions;

1- What are performance standards most required for the Yemeni EFL teachers?

2- What are the bases of a proposed blended-learning program based on the progressive theory intended to develop the Yemeni EFL teachers' performance?

3- What is the conception of a proposed blended-learning program based on the progressive theory?

4- What is the effect of the application of the proposed program on developing the Yemeni EFL teachers' linguistic performance?

5- What is the effect of the application of the proposed program on developing the Yemeni EFL teachers' pedagogical performance?

\section{Hypotheses of the study:}

1- There is a statistically significant difference between the mean scores of participants in the pre-post administration of performance test at the level (0.01) in favor of the posttest.

2- There is a statistically significant difference between the mean scores of participants in the pre-post administration of performance standards observation checklist at the level (0.01) in favor of the post administration. 


\section{Significance of the study:}

The research is significant because of the following:

- It helps in developing and enhancing the Yemeni EFL teachers' performance both linguistically and pedagogically.

- Besides, it helps in providing curriculum designers and instructors of EFL with more information about the positive effects of blended learning, which in turn, can be put into account when designing and/or teaching a syllabus.

\section{Delimitations:}

The research will be delimited to:

1- The Yemeni EFL teachers enrolled in study at the English Department, Al-Showkani Higher Institute for Qualifying and Training Teachers, both as users of EFL and as prospective teachers of English in Yemen.

2- Developing the Yemeni EFL teachers' performance both linguistically and pedagogically through using a blended learning program based on the progressive theory.

\section{The theoretical framework of the study: Progressivism:}

As a broad philosophy based on the idea of progress,_progressivism according to (Ornstein \& Hunkins, 2013) is considered a contemporary liberal reform movement in educational, social, and political affairs. The word progress is a morphologically Latin combination of pro and gradi with the meaning of "to walk forward".

John Dewey formulated principles and beliefs of progressivism in a series of publications. Therefore, Dewey deserved to be described as the father of progressivism. In Democracy and Education, Dewey (2004) confirms that democracy and education should go hand in hand and viewed school as a miniature democratic society in which learners learn the principles necessary for democratic living. From a progressive perspective, these principles include problem solving through scientific methods.

Progressivism according to (Oliva \& 1l, 2013) makes for a learnercentered approach to education, which attempts to promote the learner's 
development, as an individual with intellectual and emotional needs, and as a social being who learns best in sharing real-life activities with others. The learner is looked at as a whole rather than as a disembodied intellect. By insisting that the needs and interests of learners must be considered and by recognizing that learners bring their bodies, emotions, and spirits to school along with their minds, progressivism attracted the attention and allegiance of educators.

Progressivism plans to blend a variety of learning styles in order to prepare the most supportive real-world experiences that interest learners. From a progressive perspective, learners are actively learning. The desks are grouped all together and learners will almost never see a teacher standing in front of the class. The teacher is to work as a facilitator, a director of learning, a guide, and a collaborative partner. The classroom is very active and more self-directed. It focuses on a democracy environment and shows case citizenship. Both art and science are brought together into the classroom. Learners are active, reflective, intuitive and being actively involved in experiential learning.

Progressivists lay great stress on the need for "learning by doing" rather than by being taught since learners are viewed as active participants shaping their own track of learning. A further aspect of progressivism is its view of the school as a self-contained community responsible for creating its own subculture and interaction among its various participants.

To sum up, progressivism is a learner-centered philosophy that believes that ideas should be examined by experimentation, and that learning takes place through finding answers for questions. This philosophy, therefore, values the scientific method of teaching, adopts problem-based learning, allows individuals to have their own beliefs, and promotes the interaction of learners as valuable to the learning process.

\section{Blended learning:}

We are living in an ever-changing world. Throughout the last few years, the fields of education have been invaded by the fast and rapid revolution of what is called world wide web (WWW). The meaning of "blended 
learning" has changed over time. Blended learning according to Friesen (August,2012) has been perceived as a combination of face-to face and technology-mediated instructional forms and practices.

Graham (2006) argues that blended learning represents the convergence of two historically separate environments, i.e., regular face-to-face learning systems and distributed learning systems. These two learning environments use different media/method combinations and address the needs of different audiences. Face-to-face learning, for example, involves person-to-person interaction in a live synchronous, high fidelity environment. On the other hand, distance learning systems typically occur in an asynchronous, low fidelity environment and emphasize self-paced learning and learning-materials interactions (pp. 4-5).

Garrison \& Vaughan (2008:4) assert that blended learning is a fusion of regular face-to-face and online learning and represents an optimally integration between face-to-face oral communication and online written communication in such a way that the strengths of each are blended into a unique learning experience consistent with the context and the intended educational purpose (pp. 5). Nowadays, the term "blended learning" simply means integrating the use of technology into course design and content delivery (Bath \& Bourke, 2010).

Blended learning is reportedly considered more effective than purely faceto-face or purely online classes. Badwi (2009) carried out a study entitled "Using blended learning for enhancing EFL prospective teachers' pedagogical knowledge and performance". The researcher concluded that blended learning is more effective in developing EFL prospective teachers' pedagogical knowledge than face-to-face mode of instruction, and that both blended learning and face-to-face have almost an equal effect on developing EFL prospective teachers' pedagogical performance. Moreover, the study indicated that internet ready-made content and emails are effective as well as accessible for designing simple blended learning courses.

Hussein (2016), for instance, carried out a quasi-experimental study intended to promote EFL literature-related reading skills and literary 
appreciation among the Yemeni college of education teacher trainees throughout the use of WebQuest. The study participants, (40) of level two student teachers at the English Department, Faculty of Education-Al Naderah, Ibb University, Yemen, were divided into two equally main groups, i.e., control and experimental.

Results showed that there was a statistically significant difference between the mean scores of participants in the experimental and control groups at the level (0.05) on literature-related reading test and literary appreciation test in favor of the experimental group. The results also revealed that the performance of participants of the experimental group in the literary appreciation test was better after the experiment than before it. The study concluded that utilizing WebQuests in teaching literary texts helped the participants promote their literature-related reading skills and improve the way they appreciate literature.

Similarly, Zaki (2017) conducted a study to investigate the effect of a proposed program based on WebQuest on developing EFL academic writing abilities of postgraduate students. Results of the study revealed that process-based academic writing instruction in an electronic learning environment is an effective approach for developing academic writing. Based on the findings, the researcher recommended the integration of improving thinking, researching, and technology use into academic writing instruction as an interwoven process.

To summarize, it may be argued that the use of blended learning can provide benefits or advantages such as the following; enabling access and flexibility, enhancing current teaching and learning practices, providing learning delivery efficiency, enhancing reflective thinking, and finally offering students a considerable chance of processing information and constructing meaning. Furthermore, the brief review of related literature revealed that blended learning is considered common in higher education and seems to be applicable to a wide range of disciplines and courses, and that there are theoretical and procedural evidences on blended learning proving its effectiveness. 


\section{EFL teachers' performance:}

Bellamy (2011) looked up the word "performance" online and found the following meanings: 1) The act of performing a work or role. 2) The way in which someone or something functions, 3) Something performed; an accomplishment, 4) the state of being performed, and 5) linguistically; one's actual use of language in actual situations.

Progressivists emphasize the importance of helping teachers to develop strategies that will allow them to evaluate and improve their own classroom performance. Therefore, EFL teachers would listen to what learners had to say about their lessons and would even encourage them to keep diaries noting their impressions and level of satisfaction regarding their language performance. Unfortunately, even though it is argued that ineffective teachers negatively impact learners' learning while effective teachers lead to higher learner achievement, educational institutions and/or organizations rarely use an appropriately teacher evaluation system to make distinctions among their teachers' performances.

Teacher evaluation is not in itself a new concept, but it has recently become a major focus for policy makers, researchers and practitioners in the field of education. Two factors have contributed to giving such considerable attention to teacher evaluation. The first according to Santiago, Benavides, Danielson, Goe, \& Nusche (2013) is recognizing that teachers are the most important factor influencing learners' achievement. Secondly, there is an increasing evidence that conventional existing approaches to teacher evaluation are not effective.

According to Virginia Board of Education (2015), there is a need to focus on the relationship between teacher performance and learners' improvement.

In this context, Abbood (2016) conducted a study with the purpose of enhancing Iraqi EFL teachers' performance and their learners' achievement through using a communicative-based training program. Two major instruments were used in the study which are an observation checklist for teachers and an achievement pre-posttest for students to 
determine the effect of the training program on their teachers' teaching performance.

Results of the study showed an improvement in teachers' performance, which in turn, resulted in enhancing their students' achievement. However, it was noticed that teachers' performance and their students' achievement are not in harmony with CLT for many reasons, i.e., lack of training programs on CLT, lack of enough support from administration to such modern approaches, unsuitability of a western educational system in an EFL context, large classes, and ultimately most of students are inactive to participate with, if not are incapable of learning according to CLT.

Abd Elmenam (2015) conducted a study to identify the effect of using a task-based learning approach on developing university teacher trainees' performance in teaching English language. An observation sheet including performance indicators most appropriate for participants of the study was developed. In addition, the observation sheet was provided with a rating scale describing four levels of performance on a continuum arranged from excellent to poor.

Results of the study revealed that there was a statistically significant difference between the mean scores of participants in the pre and post administration of performance observation sheet in favor of the post administration. This, in turn, asserts that the suggested program has had a very large effect on developing the research participants' performance in teaching English language in relation to planning, management, language, assessment, and professionalism domains. Furthermore, it is worth noting that Abd Elmenam's study provided the researcher with some valuable remarks on how to prepare observation checklists.

Roughly, there is a consensus with reference to performance standards most required for teachers of language. these performance standards are specifically related to seven domains (i.e., language proficiency or professional knowledge, instructional planning, instructional delivery, assessment of and for student learning, learning environment, professionalism, and finally student academic progress. 
Furthermore, it could be argued that a performance-based teacher evaluation system involving all aspects of the profession is needed for quality assurance as well as considerably regarded a contributor to both professional development and professional improvement of EFL teachers and consequently leading to enhancing learners' learning outcomes. Thus, Professional development for English language teachers according to British Council (2012) is a continuous process that takes place across all the stages of a teacher's career. The continuous process of professional development emphasizes the importance of reflecting upon what is performed as an essential part of the process of development as well as helps EFL instructors improve their performance, build professional relationships, overcome their work challenges, and achieve their objectives. Some of the forms professional development takes can be summarized below as:

- Conferences; attending annual conferences is of great value for EFL teachers since they will be able to discuss with each other, improve their language, and gain knowledge from the sessions introduced by experts. When teachers are experienced and confident enough, they themselves can make a presentation to share their experience with others, and meanwhile this is considered a good professional development activity for them as well.

- Networking; networking with other teachers is one of the most stimulating ways to develop professional growth. There are, for example, many English language teaching (ELT) Facebook and Twitter groups where an EFL teacher can subscribe and participate in discussing common issues and sharing a teaching idea with other teachers. - Observation; to be observed and get feedback from a trusted classmate can give a teacher of English a fresh perspective on his/her teaching, and thus help to identify areas he/she would like to develop.

- Monitoring; learning from a more experienced peer is an invaluable way to gain more insights concerning current trends in the field of English language teaching. In the same way, it is a good activity to monitor a less experienced peer if you are getting an experienced teacher. - Reflection; 
the ability to reflect upon one's own classroom practice is viewed to be a unique experience and an essential skill for an EFL teacher through which areas of strengths and weaknesses are profoundly considered.

\section{Progressivism, blended learning, and EFL teachers' performance:}

From the above theoretically mentioned framework, it has been made clear that the philosophical school of progressivism and blended learning system constitute a remarkably tangible binary in a sense that there are many points of convergence between them. For instance, but not exclusively, the progressive theory emphasizes experiential learning, diversifying learning environments, learning by doing, and learners' taking responsibility of their own learning, and these insights all are practically applied through blended learning instruction. Thus, progressivism undoubtedly is the theory on the basis of which the selection of the topics of the training program of the study has been inspired, and blended learning is the practical field for a real representation of its thoughts, visions and principles in the form of the tasks and activities of the program. Furthermore, it might be hoped that the employment of this consistently two-wings binary in achieving the goal of this study represented in developing the Yemeni EFL teachers' performance both linguistically and pedagogically would probably give its desired effect.

\section{Methodology:}

The present study adopted the one group quasi experimental design and the participants were 16 male and female teachers enrolled in study at the English Department, Al-Showkani Higher Institute for Qualifying and Training Teachers. Data was collected through three main instruments which can briefly be described as follows:

- A pre-post observation checklist including performance standards with three indicators each most required for assessing the Yemeni EFL prep-stage teachers in relation to four main domains (i.e., language competency, planning and organization, instructional delivery, and assessment. The checklist has been adapted from Virginia Board of Education (2015) and prepared in the light of the principles of progressivism as a philosophical base on which the dissertation relied. 
- A pre-post performance test intended to measure the Yemeni EFL prep-stage teachers' performance before and after the application of proposed training program.

- A self-assessment sheet intended to explore the participants' level of satisfaction towards the proposed blended-learning program employed in the experiment of the study as well as to involve them in the process of evaluation as an important aspect of progressive assessment.

The contribution of the study was the blended-learning program based on progressivism aiming to develop the Yemeni EFL teachers' performance both linguistically and pedagogically. The process of designing the program proceeded through two major phases, i.e., first, selecting the topics which are more suitable for the program from a progressive perspective where the focus was on thematic topics (topics with a theme), second, preparing tasks and activities most appropriate for blended learning. Some examples of the topics tackled during the program implied first language acquisition, fluency versus accuracy, technology and interactive media and language teaching/learning, teaching citizenship, problem-based learning, leadership, feedback on learner's language, assessment, and how to construct a test.

\section{Results and discussion:}

The results were discussed in the light of the research hypotheses as follows.

\section{Hypothesis (1);}

There is a statistically significant difference between the mean scores of participants in the pre-post administration of performance standards observation checklist at the level (0.01) in favor of the post administration.

To test this hypothesis, the $t$-test for paired samples was used to compare between the mean scores of participants in the pre-post administration of performance standards observation checklist. Results of the test were presented in the table below. 
Results of the pre-post administration of performance standards observation checklist

\begin{tabular}{|c|c|c|c|c|c|c|c|}
\hline $\begin{array}{c}\text { Performance } \\
\text { obs. checklist }\end{array}$ & $\mathrm{N}$ & $\mathrm{M}$ & $\mathrm{SD}$ & Diff. & $t$ & $\mathrm{df}$ & $\begin{array}{c}\text { Sig.(2- } \\
\text { tailed) }\end{array}$ \\
\hline $\begin{array}{c}\text { Pre- } \\
\text { administration }\end{array}$ & 16 & 59.375 & 8.090 & 12.250 & 14.685 & 15 & 0.000 \\
\hline $\begin{array}{c}\text { Post- } \\
\text { administration }\end{array}$ & 16 & 71.625 & 7.384 & & & & \\
\hline
\end{tabular}

The above table revealed that the mean scores of participants in the preadministration of performance standards observation checklist was (59.375) with a standard deviation of (8.090) and the mean of postadministration was (71.625) with a standard deviation of (7.384) and the difference between them was (12.250), and that the computed $t$-value was (14.685) which is highly and statistically significant at the level (0.000).

\section{Hypothesis (2):}

There is a statistically significant difference between the mean scores of participants in the pre-post administration of performance test at the $(0.01)$ level in favor of the posttest.

To verify the hypothesis, the $t$-test for paired samples was used to compare between the mean scores of participants in the pre-post administration of performance test. Results of the test are introduced in this table.

\section{Results of the pre-post administration of performance test}

\begin{tabular}{|c|c|c|c|c|c|c|c|}
\hline $\begin{array}{c}\text { Performance } \\
\text { test }\end{array}$ & $\mathrm{N}$ & $\mathrm{M}$ & $\mathrm{SD}$ & Diff. & $T$ & $\mathrm{df}$ & Sig. \\
\hline $\begin{array}{c}\text { Pre- } \\
\text { administration }\end{array}$ & 16 & 17.125 & 7.865 & 48.375 & 14.445 & 15 & 0.000 \\
\hline
\end{tabular}




\begin{tabular}{|c|c|c|c|c|c|c|c|}
\hline $\begin{array}{c}\text { Post- } \\
\text { administration }\end{array}$ & 16 & 65.500 & 15.310 & & & & \\
\hline
\end{tabular}

The above table showed that the mean scores of participants in the preadministration of performance test was (17.125) with a standard deviation of (7.865) and the mean of post-administration was (65.500) with a standard deviation of (15.310) and the difference between them was (48.375), and that $t$-value computed was (14.445) which is highly and statistically significant at the level (0.000). Accordingly, hypothesis (2) is accepted.

\section{Conclusions:}

The present study reached the following main conclusions:

1- The participants performed better (at the level 0.000) in the postadministration of performance standards observation checklist as whole and in each of its four domains apart than they performed in the pre-administration.

2- The participants' performance in the overall performance test postadministration (at the level 0.000) outperformed their performance in the pre-administration.

3- In relation to the observation checklist, the effect size of the proposed blended-learning program based on the progressive theory was large (at the level 0.934) in developing the Yemeni EFL teachers' performance both linguistically and pedagogically.

4- In relation to performance test, the effect size of the proposed program was large (at the level 0.932) in developing the Yemeni EFL teachers' performance.

Besides, it might not be forgotten to indicate that the results of the present study were in conformity both with the results of studies conducted by Nassar (2017); Alhamzi (2017); Hussein (2016); Ali (2012); Badwi (2009) with regard to revealing the effectiveness of blended learning, and with Yousif (2017); Abbood (2016); Zuheer (2013) with respect to developing EFL teachers' performance. 


\section{Pedagogical implications:}

Based on the completed course of the study, many useful pedagogical implications can be denoted as follows:

At the outset, the main contribution of the study might fortunately be that it succeeded not merely in embedding content of the blended-learning program employed in the present study some of theoretical principles of progressivism, but also in attempting to get participants transform those principles into practical realization and/or tangible practice while doing their microteaching practicum. In addition, what should be denoted of the program topics is that they were characterized by novelty (examples of such topics are teaching citizenship, problem-based learning, leadership, and assessment for learning) and originality as well. The rationale for selecting them was their consistency with the principles of the progressive theory.

Another remark of the study was likely represented in trying to successfully employ instructional technology (i.e., electronic learning as one principal component of blended learning) in enhancing level of the Yemeni EFL teachers' performance both linguistically and pedagogically. For instance, throughout the session entitled "technology and interactive media and language teaching/learning", participants were introduced with explanations of some basically relevant concepts like digitized readings and analog materials, software programs, E-books, webcasts, virtual classroom, broadcast and streaming media, the internet, hypertext, and hypermedia which if wisely used, can help support language learning, establish relationships with the society and encourage social engagement with their peers, and facilitate active and creative use of technology applications.

Moreover, one of the most positive aspects of the program was that it provided participants with a variety of communicative blended-learning tasks and activities. Such tasks and activities allowed them to be engaged in natural spontaneous use of language, grow through experience, explore ideas from their own perspectives, collaborate and think creatively to solve problems, acquire some techniques of successful leadership, and ultimately 
create a democratic atmosphere in the classroom where they could, even at a minimum level, practice values of freedom, justice, equality, tolerance, and openness.

In conclusion, it may be inferred that the integration between online and computer-mediated learning and face-to-face sessions was what might allow the present study to reach such remarkable results on the one hand. On the other hand, the integration of the topics of the program and their conformity with the principles of the progressive theory was probably what gave the proposed training program that highly positive effect on developing the Yemeni EFL teachers' performance both linguistically and pedagogically in relation to the four domains determined earlier on.

\section{Recommendations:}

Based on the findings of the study, the researcher recommends the following:

- Education policy makers should instantly start adopting online and blended learning as a major component of programs of preparing EFL teachers along with conventional face-to-face interaction.

- Considering content of the designed blended-learning program based on the progressive theory employed in the present study as a basic course for Yemeni EFL prospective teachers.

- With its considerably huge content, progressivism represents a philosophical base for many other further researches on the area of applied linguistics.

EFL in-service instructors should have some training courses on how to utilize blended learning.

- The necessity of providing pedagogy practitioners with some information regarding the different models of blended learning.

- Language teachers should pay greater attention to the importance of varying styles of learning for their students rather than attempting to force them into a single style of learning. 
- Citizenship is not only to be taught to young people in our schools' syllabuses, but also to be practiced and demonstrated to prepare them for the challenges and opportunities of an everchanging world.

\section{Suggestions:}

In the light of the study results, further researches are suggested below as follows:

- Exploring the Yemeni EFL teachers' perspectives towards blended learning.

- Employing E-learning in enhancing the Yemeni EFL teacher trainees' performance.

- Using a blended-leaning program based on post constructionism to develop language proficiency of EFL teachers.

- Improving EFL teachers' fluency utilizing the communicative language teaching approach.

- Integrating asynchronous online learning with synchronous learning to enhance the communicative competence among EFL student teachers.

\section{References}

Abbood, R. A. (2016). "A communicative-based training program to enhance Iraqi EFL teachers' performance and their students' achievement" 89-91. Doctoral dissertation. Ain Shams University.

Abd Elmenam, M. A. E. (2015). "The effect of using task-based learning approach on developing university student-teachers' performance in teaching the English language" 99-100. Doctoral dissertation. Ain Shams University, Egypt.

Alhamzi, A. M. A. (2017). "The effectiveness of strategies of blended learning and peer learning on developing overt reading and functional writing skills among the seventh preparatory grade students". Doctoral Disseertation. Ain Shams University, Egypt.

Ali, M. F. (2012)."The effectiveness of a suggested blended learning program in enhancing English language majors' speaking skills". Master's thesis. Ain Shams University, Egypt. 
Azizan, F.Z. (2010). "Blended learning in higher education. Institution in Malaysia". Proceedings of Regional Conference on Knowledge Integration in ICT.

Badawi, M. F. (2009). "Using blended learning for enhancing EFL prospective teachers' pedagogical knowledge and performance", pp. 24. Conference Paper: Learning \& Language - The Spirit of the Age, 14-15 March 2009, Ain Shams University Guest House, Cairo, Egypt.

Bath, D. \& Bourke, J. (2010). "Getting started with blended learning" (pp. 1, 4, 8, 20-22). Griffith Institute for higher Education.

Bellamy, M. (2011). "What is teacher's performance?". Retrieved January 25, 2016, from http://img.tfd.com/m/sound.swf

British Council (2012). "Going forward: Continuing professional development for English language teachers in the UK". UK: Brand and Design/152.

Dewey, J. (2004). "Democracy and education". New York: Dover publications.

Friesen, N. (August, 2012). "Report: Defining blended learning".

Garrison, D. R. \& Kanuka, H. (2004). "Blended learning: Uncovering its transformative potential in higher education". The Internet and Higher Education (7, pp. 95-105).

Garrison, D. \& Vaughan, N. (2008). "Blended learning in higher education: Framework, principles, and guidelines". San Francisco, CA: John Wiley \& Sons.

Graham, C.R. (2006). "Blended learning systems: Definition, current trends, and future directions", in C. J. Bonk \& C. R. Graham (Eds.), "The handbook of blended learning: Global perspectives, local designs" (pp. 321). San Francisco: Jossey Bass/Pfeiffer.

Hopper, K (2003). "Reasons to go hybrid". Distance Education Report. Vol. 7 (24), pp. 7.

Husein, M, A. M. (2016). "Utilizing WebQuests to promote EFL literaturerelated reading skills and literary appreciation among Yemeni college of education students". Doctoral dissertation. Mansoura University, Egypt. 
International journal of progressive education 9 (1). (2013). "Progressive education: Past, present, and future", (pp. 7, 10). International association of education (INASED).

King, K (2002). "Identifying success in online teacher education and professional development". Internet and higher education. Vol. 5, pp. 231246.

Lim, D. H., \& Morris, M. L. (2009). "Learner and Instructional Factors Influencing Learning Outcomes within a Blended Learning Environment". Educational Technology \&Society, 12 (4), 282-293.

Marsh, D. (2012). "Blended learning: Creating learning opportunities for language learners". New York: Cambridge University Press.

Nassar, N. M. (2017). "The effectiveness of an English blended-based program in enhancing the integration of tenth graders' reading of English narrative texts and their critical writing abilities". Doctoral dissertation. Ain Shams University, Egypt.

Oliva, P.\& 11,W.G. (2013)."Developing the curriculum" (pp. 132-133). Pearson Inc.

Ornstein, A. \& Hunkins, F. (2013)."Curriculum foundations, principles, and issues" (sixth ed., p p.39). Pearson Education Inc.

Rooney, J. E. (2003). "Blended learning opportunities to enhance educational programming and meetings". Association management, 55(5), 26-32.

Sadovnik, A. R., Cookson, P. W., \& Semel, S. F. (2001). "Exploring education: An introduction to the foundations of education". Boston: Allyn and Bacon.

Santiago, P, Benavides, F, Danielson, C, Goe, L and Nusche, D (2013). "OECD reviews of evaluation and assessment in education: Teacher evaluation in Chile. Paris, France": OECD.

Saritepeci \& Mustafa, et al. (2015). "The effect of blended learning environments on student motivation and student engagement: A study on social studies course". Education and Science.

Virginia Board of Education (2015, July 23). "Guidelines for uniform performance standards and evaluation criteria for teachers" (pp. 3-4, 7-8, 59-60). Virginia: James H, Stronge. 
Yousif, A. F. (2017). “A training program based on Gardner's five minds model to develop EFL teachers' teaching performance skills in the light of $21^{\text {st }}$ century skills." Doctoral dissertation. Ain Shams University, Egypt.

Zaki, E. M. F. (2017). "A suggested programme based on WebQuest for developing postgraduate students' EFL academic writing abilities". Doctoral dissertation. Ain Shams University, Egypt.

Zuheer, K. M. (2013). "Developing EFL teachers' performance at Sana'a secondary schools in the light of their professional and specialist needs". Doctoral dissertation. Institute of educational studies, Cairo University 